\title{
Thermal Analyses of Briquette Fuels Produced from Coal Dust and Groundnut Husk
}

\author{
Ikelle I. Ikellea*, Nworu J. Sundaya, Nworie F. Sundayb, Jedidiah John'b, Ogbuagu J. Okechukwuc and \\ Nwabueze I. Elom d
}

a School of Basic Science (Chemistry), Nigeria Maritime University Okorenkoko, PMB 1005 Warri South West, Delta State, Nigeria.

b Department of Industrial Chemistry, Ebonyi State University Abakaliki, PMB 053 Ebonyi State, Nigeria.

c Department of Pure and Industrial Chemistry, Nnamdi Azikiwe University Awka, PMB 5025 Anambra State, Nigeria.

d Department of Chemistry/Biochemistry/Molecular Biology, Alex Ekwueme Federal University Ndufu-Alike, Ikwo, PMB 1010, Ebonyi State, Nigeria.

*Corresponding Author E-mail: iikelle@ymail.com; Phone Number: +2348035649755

\section{DOI: 10.2478/acmy-2020-0004}

\begin{abstract}
:
This work involved the production and thermal characterization of biomass briquettes produced by blending a major agricultural waste with coal dust. In the work, nine different compositions of coal dust/groundnut husk briquettes were produced using starch as the binder while $\mathrm{Ca}(\mathrm{OH} 2)$ was incorporated as the de-sulphurizing agent. The ash content, volatile matter, fixed carbon, moisture content, compressive strength, ignition time, calorific value, water boiling test and burning rate were carried out to determine the physical, mechanical and thermal properties of the briquettes produced. The results showed that moisture content values are in the range $2.43-6.44 \%$, for compressive strength $7.72-10.85 \mathrm{~N} / \mathrm{mm} 3$, for ash content $24.18-29.15 \%$, for calorific value $21714.17-25027.18 \mathrm{~kJ} / \mathrm{kg}$, for fixed carbon $16.77-53.22 \%$, for ignition time 22.23-45.20 s, for water boiling test 1.50-4.99 min and burning rate 16.10$28.32 \mathrm{~g} / \mathrm{min}$. These are appreciable values for the thermal properties of the bio-briquettes. Therefore, the agro-wastes briquettes are beneficial for heating purposes rather than open incineration of the wastes.
\end{abstract}

Keywords: Agro-waste, ash, binder, bio-coal, biomass, briquette.

\subsection{Introduction:}

Solid waste management is one of the major problems in Nigeria. This is not only found in the urban areas but also at the rural areas. The major waste generated at the rural areas is agricultural waste or residue (crop by-product). Despite this level of waste generation, the rural dwellers still rely on wood fuel and charcoal fuel for heating, cooking and other purposes [1]. These agricultural wastes are regarded as renewable energy sources, they are thought to be a better option since the non-renewable such as kerosene, diesel, gasoline have the capability not to be replenished and would be exhausted. More so, the environmental impacts as a result of emissions of $\mathrm{CO}_{2}, \mathrm{SO}_{2}, \mathrm{NO}_{\mathrm{x}}$ during combustion of the non-renewable resources, prompted the use of renewable for cooking and heating purposes [2]. Bio-coal briquettes have wide range of industrial and domestic applications, with very lower ash content, long shelf-life and no danger of fire or explosion of the fuel. It saves the trees as the practice of cutting of trees for fuel is replaced by these better quality briquettes. The briquettes are bio-degradable fuel that does not leave residues and cause contamination to the water and soil. It also acts as a good substitute for polluting fuels as well as costly renewable energy resource and they can be produced in almost every part of the world where bio-mass is easily available [3].

Bio-coal briquette is a type of solid fuel prepared by compacting pulverized coal, biomass, binder and sulphur fixation agent. The high pressure involved in the process ensures that the coal and the biomass particles are sandwiched and adhered together, as a result they do not separate during transportation, storage and combustion. During combustion, the co-combustion of the coal and the biomass gives a better combustion performance and reduces pollutant emission that is bio-coal briquette has a favorable ignition, better thermal efficiency, emits less dust and soot [4]. The mechanism behind this is that, since the biomass component of the briquette ignites at low temperature compared to the coal, this ensures that the volatile matter in the coal which would have otherwise be liberated as smoke at low combustion temperature combusts completely. Furthermore, the presence of sulphur fixation agent known as desulfurizing agent ensures that most of the sulphur content of the coal is fixed into the ash instead of being liberated into the atmosphere as $\mathrm{SO}_{2}$ [5].

The use of briquetting for conversion of agricultural residues is comparatively recent, however, and has only been taken up in developing countries in the last few years. Main agricultural residues that are produced are rice husk, coconut dregs, hay, groundnut husk, jatropha husk, palm nut shell, corn cob and cotton stem. Beside the problem of transportation, storage and operation, open burning of this bio waste with traditional style without control has continued to cause critical air pollution. Agricultural waste covers a wide range of different species which show large variation in composition and fuel characteristics [6]. However, the percentage composition of the combustible elements in the agricultural waste whether in loose form or briquette form are very low compared to fossil fuels [7]. Hence the low emissions of the oxides of the combustible elements, the emission of $\mathrm{CO}_{2}$ form the combustion of biomass (agricultural waste) is equivalent to the amount of $\mathrm{CO}_{2}$ absorbed during its growing cycle, so the net $\mathrm{CO}_{2}$ released is approximately zero by mass [8].

The impact of agricultural waste on the environment depends not only on the amounts generated but also on the disposal methods used. Some of the disposal practices pollute the environment. The potential threat posed by climate change, due to high emission levels of greenhouse gases $\left(\mathrm{CO}_{2}\right.$ being the most important one), has become a major stimulus for renewable energy sources in general. When produced by sustainable means, biomass emits roughly the same amount of carbon during conversion as is taken up during plant growth. The use of biomass therefore does not contribute to a buildup of $\mathrm{CO}_{2}$ in the atmosphere [9]. Hence the need at the moment in the densification of this agricultural waste in developing countries is the development of an appropriate briquetting machine suitable to the local communities. For biomass to make a significant impact as fuel for rural communities, it is imperative that an efficient, cost effective and easy to duplicate technology is developed specifically for rural communities.

The objective of the study is to produce smokeless briquettes from coal and groundnut husk. To investigate whether the thermal properties of briquettes produced would show the briquettes are good source of heat energy, thereby serving as alternative to wood fuel to mitigate against deforestation.

\subsection{Materials and Methods}

\subsection{Preparation of the samples}

The Sub-bituminous coal sample from Onyeama mine was sourced at Nigeria Coal Corporation, Enugu, sundried to reduce its moisture content, broken into smaller sizes, ground in an electric milling machine to pass through $1 \mathrm{~mm}$ sieve and stored. The groundnut husk was collected from Kpirikpiri market at Abakaliki, sun dried, ground and sieved through $1 \mathrm{~mm}$ sieve and stored.

\subsection{Preparation of the briquette samples}

The briquettes were produced using a manual hydraulic briquetting machine with three cylindrical moulds. Briquettes of coal and groundnut husk of different compositions were produced by the addition of $30 \mathrm{~g}$ of $\mathrm{Ca}(\mathrm{OH})_{2}$ as de-sulphurizing agent, while $20 \mathrm{~g}$ of starch dissolved in hot water was added as binder. The blend was added $50 \mathrm{ml}$ of water and mixed properly until a paste was formed, scooped and placed in the mould. The pressure and compression force of $276.36 \mathrm{~N}$ and $31.67 \mathrm{~N} / \mathrm{m}^{2}$ was maintained for $20 \mathrm{~min}$ before the briquettes were extruded. After production, the briquettes were sun dried for 7 days before analyses [9]. 


\subsection{Characterization of the briquette blends}

\subsubsection{Combustion Analysis}

The combustion analysis was carried out to determine the combustion characteristics of the briquette blends that were produce d.

1. Ignition time (s): The different samples were ignited at the edge of their bases with a Bunsen burner. The time taken for each briquette to catch fire was recorded as the ignition time using a stopwatch [10].

2. Burning time (min): The time taken for $50 \mathrm{~g}$ of each of the briquette blends to burn completely to ashes. Subtracting the time it turned to ashes completely from the ignition time gives the burning time [10].

Burning time $=$ Ashing time - Ignition time

3. Water boiling test (min): This was carried out to compare the cooking efficiency of the briquettes. It measures the time taken for each set of briquettes to boil an equal volume of water under similar conditions. During the process, $100 \mathrm{~g}$ of each briquette sample was used to boil $250 \mathrm{ml}$ of drinking water using small stainless cups and domestic briquette stove. The boiling test was monitored visually until the water started boiling [10].

4. Calorific value: The calorific values of the briquettes were determined using Oxygen Bomb Calorimeter of model-0SK $100 \mathrm{~A}$. The calorific value (kJ/kg) of the samples under test was calculated from the temperature rise in the calorimeter vessel and the mean effective heat capacity of the system [11].

$\mathrm{VI}=\frac{\left(\mathrm{Ee}+\mathrm{W}_{1}\right) \mathrm{TR}-\mathrm{C}}{\mathrm{S}} \mathrm{X} 4.1868$

Where Ee is the water equivalent of the calorimeter $(581 \mathrm{~g}), \mathrm{W}_{1}=$ quantity of water in the vessel, $\mathrm{TR}=\mathrm{Temperature}$ rise ${ }^{\circ} \mathrm{C}$, $\mathrm{C}=\mathrm{correction}$ factor from ignition $154 \mathrm{Cal}, \mathrm{S}=$ weight of sample in grams $(\mathrm{g})$.

\subsubsection{Proximate analyses of the briquette blends}

1. Moisture content: The moisture contents of the briquettes were determined. A portion $2 \mathrm{~g}$ each of the briquette samples that were sundried for 7 days was weighed out in a wash glass. The samples were placed in an oven heated for 2 hours at $105^{\circ} \mathrm{C}$. The moisture content was determined according to ASTM standard [12].

$\mathrm{MC}=\frac{\mathrm{W}_{1}-\mathrm{W}_{2}}{\mathrm{~W}_{1}} \times 100$

$\mathrm{W}_{1}=$ Initial weight, $\mathrm{W}_{2}=$ Weight after drying

2. Ash content: In the determination of the ash contents of the briquettes, a portion $2 \mathrm{~g}$ of the briquette sample that were sundried for 7 days were placed in a pre-weighed porcelain crucible and transferred into a preheated muffle furnace set at a temperature of $600 \stackrel{\circ}{\circ}$ for 1 hour after which the crucible and its contents were transferred to a desiccator and allowed to cool. The crucible and its content were reweighed and the new weight noted. The percentage ash content was calculated using ASTM standard [12]

$\mathrm{AC}=\frac{\mathrm{W}_{2}}{\mathrm{~W}_{1}} \times 100$

$\mathrm{W}_{1}=$ Original weight of dry sample, $\mathrm{W}_{2}=$ Weight of ash after cooling.

3. Volatile matter: The volatile matter of the briquettes was also determined. A portion $2 \mathrm{~g}$ of the briquette samples sundried for 7 days was heated to about $300{ }^{\circ} \mathrm{C}$ for 10 minutes in a partially closed crucible in a muffle furnace. The crucible and its content were retrieved and cooled in a desiccator. The difference in weight was recorded and the volatile matter was calculated using ASTM standard [12].

$\mathrm{VM}=\frac{\mathrm{w}_{1}-\mathrm{W}_{2}}{\mathrm{~W}_{1}} \times 100$

$\mathrm{W}_{1}=$ Original weight of the sample. $\mathrm{W}_{2}=$ Weight of sample after cooling.

4. Fixed carbon: The fixed carbon of the briquettes was also determined using the formula according to ASTM standard [12].

$\mathrm{FC}=100-(\% \mathrm{VM}+\% \mathrm{AC}+\% \mathrm{MC})$

Where $\mathrm{VM}=$ Volatile matter $\mathrm{AC}=$ Ash content, $\mathrm{MC}=$ Moisture content

5. Determination of the Compressive Strength: Compressive strength in cleft of briquettes was determined in accordance with ASTM, using an Instron Universal Strength testing machine with load cell capacity of $100 \mathrm{kN}$ [13]. The cross-head speed was $0.305 \mathrm{~mm} / \mathrm{min}$. A sample of briquette to be tested was placed horizontally in the compression test fixture and a load was applied at a constant rate of $0.305 \mathrm{~mm} / \mathrm{min}$ until the briquette failed by cracking. The compressive strength in cleft was then computed as follows:

Compressive strength in cleft $\left(\frac{\mathrm{N}}{\mathrm{mm}}\right)=3 \times \frac{\text { The load at fracture point }(\mathrm{N})}{\left[\mathrm{l}_{1}(\mathrm{~mm})+\mathrm{l}_{2}(\mathrm{~mm})+\mathrm{l}_{3}(\mathrm{~mm})\right]}$

Where $l_{1}, l_{2}$ and $l_{3}$ were lengths of briquettes at points one, two and three, respectively in (mm).

\subsection{Results}

Table 1: Proximate Analyses of Bio-coal Briquettes of Groundnut Husk

\begin{tabular}{|c|c|c|c|c|c|}
\hline Samples & Ash content (\%) & Volatile matter (\%) & Fixed carbon (\%) & Moisture content (\%) & Compressive strength $\left(\mathrm{N} / \mathrm{mm}^{3}\right)$ \\
\hline $0 \%$ & 24.18 & 20.17 & 53.22 & 2.43 & 7.72 \\
\hline $10 \%$ & 24.75 & 23.28 & 49.49 & 2.48 & 8.43 \\
\hline $20 \%$ & 25.08 & 26.72 & 44.83 & 3.37 & 9.47 \\
\hline $30 \%$ & 25.65 & 28.15 & 42.29 & 3.91 & 9.91 \\
\hline $40 \%$ & 26.25 & 31.77 & 37.83 & 4.15 & 10.85 \\
\hline $50 \%$ & 27.02 & 34.82 & 33.68 & 4.48 & 10.36 \\
\hline
\end{tabular}




\begin{tabular}{llllll}
\hline & & & & 5.02 & 10.21 \\
$70 \%$ & 27.52 & 36.95 & 30.51 & 5.44 & 9.83 \\
$80 \%$ & 28.00 & 39.52 & 27.04 & 5.86 & 8.76 \\
$90 \%$ & 28.43 & 42.01 & 26.30 & 6.12 & 8.21 \\
$100 \%$ & 28.85 & 44.15 & 20.88 & 6.44 & 7.84 \\
\hline
\end{tabular}

Table 2: Combustion Analyses of Bio-coal Briquettes of Groundnut Husk

\begin{tabular}{lllll}
\hline Samples & Calorific value $(\mathrm{kJ} / \mathrm{kg})$ & Ignition time $(\mathrm{s})$ & Burning time $(\mathrm{min})$ & Water boiling test $(\mathrm{min})$ \\
\hline $0 \%$ & 25027.18 & 45.20 & 28.32 & 1.50 \\
$10 \%$ & 24788.28 & 42.76 & 26.54 & 1.77 \\
$20 \%$ & 24340.63 & 39.12 & 25.12 & 2.21 \\
$30 \%$ & 23947.58 & 36.21 & 23.41 & 2.66 \\
$40 \%$ & 23628.88 & 35.76 & 22.56 & 2.89 \\
$50 \%$ & 23225.69 & 33.16 & 21.51 & 3.41 \\
$60 \%$ & 22850.80 & 32.73 & 19.50 & 3.98 \\
$70 \%$ & 22520.30 & 31.31 & 19.15 & 4.35 \\
$80 \%$ & 22765.31 & 29.20 & 18.33 & 4.65 \\
$90 \%$ & 21956.25 & 22.91 & 16.65 & 4.99 \\
$100 \%$ & 21714.17 & & 16.10 & \\
\hline
\end{tabular}

\subsection{Discussion of results}

The results of the physico-thermal properties of the briquette blends are presented in table 1 . The ash content of the coal briquette is the amount of ash that remains after the briquette is incinerated. The results showed a rise in ash content as the biomass was blended with coal dust, in the range of (24.75$29.15 \%$ ). According to Loo and Koppejan, the higher the fuel's ash content, the lower the calorific value, this was witnessed in the reduction of the calorific values as the biomass was blended with the coal dust from $(25027.18-21714.17 \mathrm{~kJ} / \mathrm{kg})$ [14]. The fixed carbon of a fuel is the percentage of carbon available for char formation during combustion [15]. The table showed that briquette blends produced from of coal dust and groundnut husk by varying their compositions resulted in briquettes with reduced fixed carbon content values from (53.22 to $16.77 \%$ ). The findings compared favorably with the work of Ajueyitsi and Adegoke [16].

The calorific (heating) value is the standard measure of the energy content of a fuel [17]. The differences in values for sample ( $0 \%$ ) with calorific value $(25027.18 \%)$ and samples (30-40 \%) with calorific values (23628.88-23947.58 \%) are not significantly high, as such biomass can be blended with coal to produce fuel source. The results showed that the briquette blends ignited faster as the biomass were introduced thereby reducing the ignition time from 45.20-22.23 s. The briquettes with more composition of groundnut husk ignited faster because of the porous nature of the briquette blends produced that allowed enough supply of oxygen which supported combustion. The burning time which describe the time taken for the briquette blends to completely burn to ashes showed significant values for the agro-wastes that was blended with the coal. With values (23.41-26.54 min) for bio-briquette blends being close to the coal briquette at (28.32 $\mathrm{min})$.

The data presented showed that briquettes consisting only of coal had a lower compressive strength value than briquettes produced from incorporating biomass. The cellulosic bonds in the biomass of the briquettes contributed to the increase in compressive strength of the briquettes. Therefore, the use of biomass combined with coal during briquetting increases the material strength of briquettes. Analysis of the data showed that the maximum strength value of compression is somewhat higher for briquettes with a $40 \%$ biomass $\left(10.85 \mathrm{~N} / \mathrm{mm}^{3}\right)$ and lowers down though using the same pressure strength in the press. The findings are corroborated by the work of Borowski $[18,19]$.

\subsection{Conclusions}

The following conclusions can be drawn from this research:

1. For briquette quality control, the thermal parameters, such as ignition time, water boiling time and compressive strength, were found to be indicators of good bio-briquettes and therefore suitable as an alternative fuel source.

2. The physico-thermal characteristics of the briquettes studied showed that bio-briquettes manufactured from coal and groundnut husk (60:40) had high compressive strength of $10.85 \mathrm{~N} / \mathrm{mm}^{3}$, significantly high calorific value of $23628.83 \mathrm{~kJ} / \mathrm{kg}$, ignited much faster at $35.76 \mathrm{~s}$ and with burning time $22.56 \mathrm{~min}$. These values showed that the bio-briquettes had appreciable thermal properties when compared with other briquette blends. Therefore, the briquettes can be used as fuel source thereby reducing dependence on wood as fuel source.

3. The study showed that the briquetting technology had a great potential for converting waste biomass into fuel for household use in an affordable, efficient and environment friendly manner. The process is economical, cheap and affordable and has been embraced by rural dwellers and low income earners.

\subsection{Acknowledgments}

We sincerely appreciate the contributions the management of Project Development Institute Enugu and Department of Industrial Chemistry, Ebonyi State University Abakaliki for allowing us carryout the tests at their laboratories.

\subsection{References}

[1] A.O. Olorunnisola, "Production of fuel briquettes from wastepaper and coconut husk admixture, agricultural engineering international", The CIGR E journal, Vol. 6, No. 6, Pp. 60-71, 2007.

[2] A.O. Kuti, "Impact of charred palm kernel shell on the calorific value of composite sawdust briquette", Journal of Engineering and Applied Sciences, Vol. 2, Pp. 62-65, 2007.

[3] C.K.W. Ndiema, P.N. Manga, C.R. Ruttoh, "Influence of die pressure on relaxation characteristics of briquetted biomass", Energy Conversion and Management, Vol. 43, Pp. 2157-2161, 2002. 
[4] P.C.W. Kwong, J.H. Wang, and C.W. Chao, "Effect of co-combustion of coal and rice husk on the combustion performance and pollutant emission", Atmospheric Environment Journal, Vol. 17, No. 4, Pp. 7462-7468, 2007.

[5] O. Somchai, B. Kunchana, and T. Duangporn, "In-situ Desulfurization of Coal Briquettes by Lime”, Department of Chemical Technology, Chulalondkorn University, Bangkok, pp. 5-10, 1998.

[6] H. Stefan, and F. Hans, "Emission of biomass combustion plants", Available from www.bayan.de/ifu/Luft/emicontrol3.htm-6k, Accessed 10 September, 2019.

[7] N.A. Musa, "Fuel characteristics of some selected biomass briquettes", International Journal of Science and Technological Research, Vol. 3, No. 6, Pp. 193201,2006

[8] D.0. Hall, and J.I. Scrase, "Will Biomass be the environmentally friendly fuel of the future", Biomass and Bioenergy, Vol. 15, Pp. 357-367, 1998.

[9] A. Katimbo, N. Kiggundu, S. Kizito, H.B. Kivumbi, and P. Tumutegyereize, "Potential of densification of mango waste and effect of binders on produced briquettes", Agric. Eng. Int:CIGR Journal, Vol. 16, No. 4, Pp. 146-155, 2014.

[10] H. Kim, S. Kazuhiko, S. Masayoshi, “Biomass briquette as a technology for desulphurizing and energy saving”, Renewable Energy Journal, Vol. 8, Pp. 33$75,2001$.

[11] I.I. Ikelle, and C. Anyigor, "Comparative thermal analysis of the properties of coal and corn cob briquettes", IOSR Journal of Applied Chemistry, 2014; 7(6): 93-97, 2014.

[12] American Society for Testing and Materials (ASTM) Annual Book of ASTM Standards, Petroleum Products, Lubricants and Fossil Fuels, New York, Section 5, Vol. 50, No. 12, pp. 210-218, 1992.

[13] American Society for Testing and Materials (ASTM). Annual Book of ASTM Standards, Standard Test Method of Compressive Strength of Wood, West Conshohocken, Pp. 2166-2185, 2008.

[14] S.V. Loo, and J. Koppejan, “The handbook of biomass combustion and co-firing”, Earthscan Publishers: Calcutta, Pp. 67-70, 2008.

[15] I.I. Ikelle, F.S. Nworie, A.O. Ogah, and N.O. Ilochi, "Study on the combustion properties of bio-coal briquette blends of cassava stalk", ChemSearch Journal, Vol. 8, No. 2, Pp. 29-34, 2017.

[16] O.N.A. Ajueyitsi, and C.O. Adegoke, "Optimum proportion of starch binder and paper waste additive in the formulation of coal briquettes for domestic cooking”, Nigerian Journal of Mechanical Engineering, Vol. 6, No. 2, Pp. 67-71, 2003.

[17] J. Ogbuagu, T. Onuegbu, I.I. Ikelle, E.U. Obini, and C. Anyigor, "The thermal characterization of onyeama coal and rice husk briquettes produced using bitumen as binder", Journal of Physical Sciences and Environmental Safety, Vol. 3, No. 1, Pp. 38-45, 2013.

[18] G. Borowski, "The possibility of utilizing coal briquettes with a biomass", Environment Protection Engineering, Wroclaw University of Technology, Vol. 33, No. 2, Pp. 79-86, 2007.

[19] J.T. Oladeji, and C.C. Enweremadu, "The Effects of some Processing. Parameters on Physical and Densification Characteristics of Corn Cob Briquettes", International Journal of Energy Engineering, Vol. 2, No. 1,22-27, 2012. 